\title{
Biological technology for the production of pear seedlings
}

\author{
Svetlana Rezvyakova*, Aleksandr Gurin, and Nikolai Revin \\ Oryol State Agricultural University named after N.V. Parakhin, Oryol, 302019, Russia
}

\begin{abstract}
Annotation. The research was carried out during the 2017-2019 period on leached chernozem according to the "Program and methodology for studying varieties of fruit, berry and nut crops" (Orel, 1999). The grafting was done by budding fifty plants of the regionalized variety of pears Muratovskaya on the seedlings of common pear tree in three replicates. The plants were placed in one row at a distance of $20-25 \mathrm{~cm}$, with a distance of $90 \mathrm{~cm}$ between the rows. In the experimental variants, watering and loosening of the soil was done as needed. The seedlings were treated with a knapsack sprayer 4 times during the growing season with an interval of two weeks, starting from the third decade of May. In the experiment there were 4 variants: 1 - control without treatments; 2 - Emistim - $1 \mathrm{ml} / \mathrm{m}^{3} \mathrm{H}_{2} \mathrm{O} ; 3$ Emistim - $1 \mathrm{ml} / \mathrm{m}^{3} \mathrm{H}_{2} \mathrm{O}+$ Gumi-30 super-universal - $15 \mathrm{ml} / 101 \mathrm{H}_{2} \mathrm{O} ; 4$ Emistim - $1 \mathrm{ml} / \mathrm{m}^{3} \mathrm{H}_{2} \mathrm{O}+$ Siliplant $-25 \mathrm{ml} / 101 \mathrm{H}_{2} \mathrm{O}$. It was revealed that the biological product Emistim has a significant stimulating effect on the growth processes in comparison to the control variant. The combined use of the biological product Emistim and complex fertilizers Gumi-30 and Siliplant helps to increase the foliage of the seedlings, leaf area, the number of roots and their total length, and, ultimately, increase the yield of standard planting material. There was no significant difference between the variants with Emistim and complex fertilizers such as Gumi-30 and Siliplant according to the studied traits. In total, in these variants, the standard seedlings of the 1st and 2nd grade were obtained, respectively, 93.2 and $95.6 \%$.
\end{abstract}

\section{Introduction}

The production of seedlings of fruit crops is one of the main directions of the horticultural industry. The durability and productivity of the variety depends on the quality of the planting material. In terms of distribution in the conditions of Central Russia, the pear tree is the second seed crop after the apple tree. The demand for the quality planting material is growing from year to year. The condition of seedlings has been significantly influenced by weather conditions [1, 2], genetically determined characteristics of varieties [3, 4], agrotechnical measures in the nursery $[5,6]$. In recent decades, the growth stimulants of biological origin, obtained based on microorganisms or the products of microorganisms' metabolism, or extracts from plants, have been widely used in the world to reproduce and increase the

*Corresponding author: lana8545@yandex.ru 
productivity of plants [7-9]. The positive results were obtained with the use of biological preparations in the cultivation of strawberries [10-12], raspberries [13], in the nursery of stone fruits [14], apple [15-17], etc. The aim of these studies was to increase the productivity of the pear nursery based on the growth biostimulator and complex fertilizers in an easily accessible form.

\section{Materials and methods}

The research was carried out during the period of 2017-2019 on leached chernozem. Fifty plants of the regionalized variety of pears Muratovskaya were grafted by budding on the seedlings of ordinary pear in three replicates. Plants were placed in one row at a distance of $20-25 \mathrm{~cm}$, with a distance of $90 \mathrm{~cm}$ between rows. In the experimental variants, watering and loosening of the soil was done as needed. The seedlings were treated with a knapsack sprayer 4 times during the growing season with an interval of two weeks, starting from the third decade of May.

In the experiment there were 4 variants: 1 - control without

treatments;

2 - Emistim - $1 \mathrm{ml} / \mathrm{m}^{3} \mathrm{H}_{2} \mathrm{O}$

3 - Emistim - $1 \mathrm{ml} / \mathrm{m}^{3} \mathrm{H}_{2} \mathrm{O}+$ Gumi-30 super-wagon $15 \mathrm{ml} / 101 \mathrm{H}_{2} \mathrm{O}$;-

4 - Emistim - $1 \mathrm{ml} / \mathrm{m}^{3} \mathrm{H}_{2} \mathrm{O}+$ Siliplant $-25 \mathrm{ml} / 101 \mathrm{H}_{2} \mathrm{O}$.

Characteristics of fertilizers:

Emistim is a metabolic product of the symbiotic fungus Acremonium lichenicola, which is isolated from the roots of ginseng. It contains the growth substances of gibberellin and cytokinin nature, beta-lactam antibiotics, etc. It increases plant immunity and regulates plant growth, especially the development of the root system.

Gumi-30 super-universal is a humus natural elixir of fertility, growth stimulator, antistress drug. It contains more than 80 macro- and microelements in an accessible form.

Siliplant is a silicon-containing fertilizer; besides silicon $\mathrm{Si}(7 \%)$ and potassium (1\%), it contains the following microelements in chelated form (mg / 1): $\mathrm{Fe}-300 ; \mathrm{Cu} 70-240 ; \mathrm{Mn}$ 150; $\mathrm{Mg}$ - 100; B - 90; Zn - 80; Co - 15 .

Gumi-30 super-universal and Siliplant were used according to the instructions. In the control variant, no treatment was performed.

The observations and counts were carried out according to the "Program and methodology for the variety study of fruit, berry and nut crops" [16]. The research results were processed by the method of analysis of variance [16].

\section{Results and discussion}

Depending on the used fertilizer and their combinations, a different effect of the treatments on the growth and development of pear seedlings was revealed. Thus, the maximum length of the growth in the control variant was $126.6 \mathrm{~cm}$, the average $-110.2 \mathrm{~cm}$ (Fig. 1). After 4-fold processing of seedlings with the biological product Emistim, these indicators increased by 6.8 and $5.7 \%$, respectively. In the variant using a mixture of Emistim with Gumi 30 fertilizer, the maximum growth length increased by $13.5 \%$, and the average growth length by $15.6 \%$. The combination of Emistim with Siliplant contributed to an increase in the studied indicators by 21.7 and $18.5 \%$, respectively. 


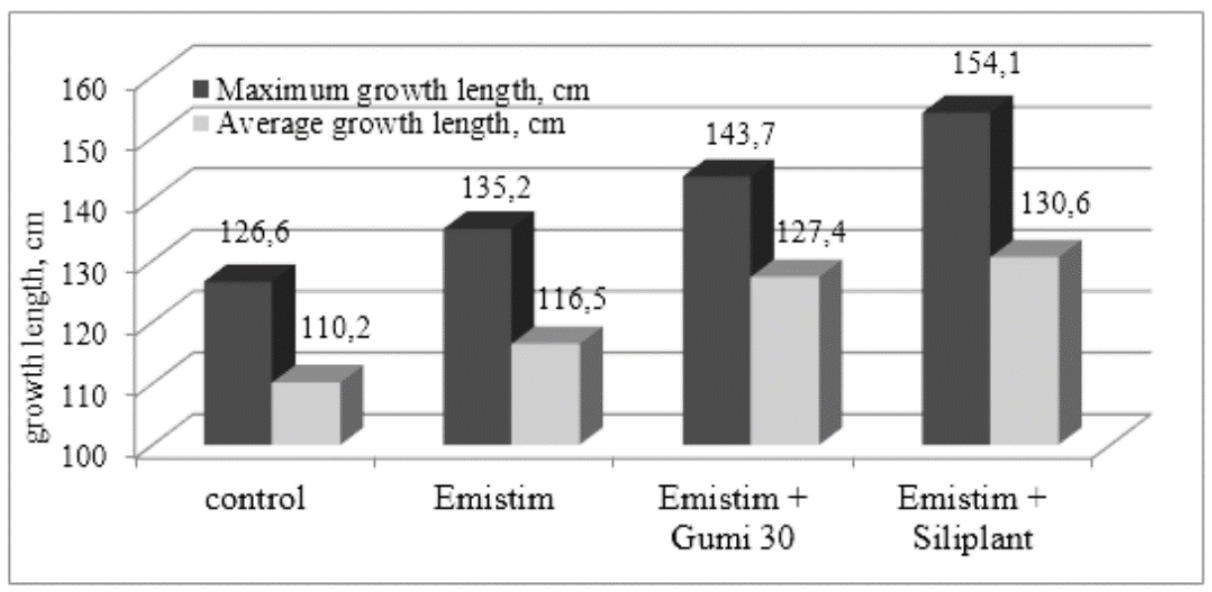

Fig. 1. The biometric indicators of pear seedlings, depending on the used fertilizer.

Pear seedlings also differed in the number of leaves and their area. In the control variant, these indicators were respectively 46.2 pcs. and $30.2 \mathrm{~cm} 2$ (Fig. 2). Under the influence of Emistim, the number of leaves increased by $9.1 \%$, the area of the leaf plate - by $7.9 \%$. In the third variant, when using Emistim and Gumi-30, the increase in the studied characteristics was 14.7 and $16.2 \%$, respectively. On the 4 th variant, when processing seedlings with Emistim and Siliplant, the number of leaves increased by $20.8 \%$, the leaf area - by $18.5 \%$.

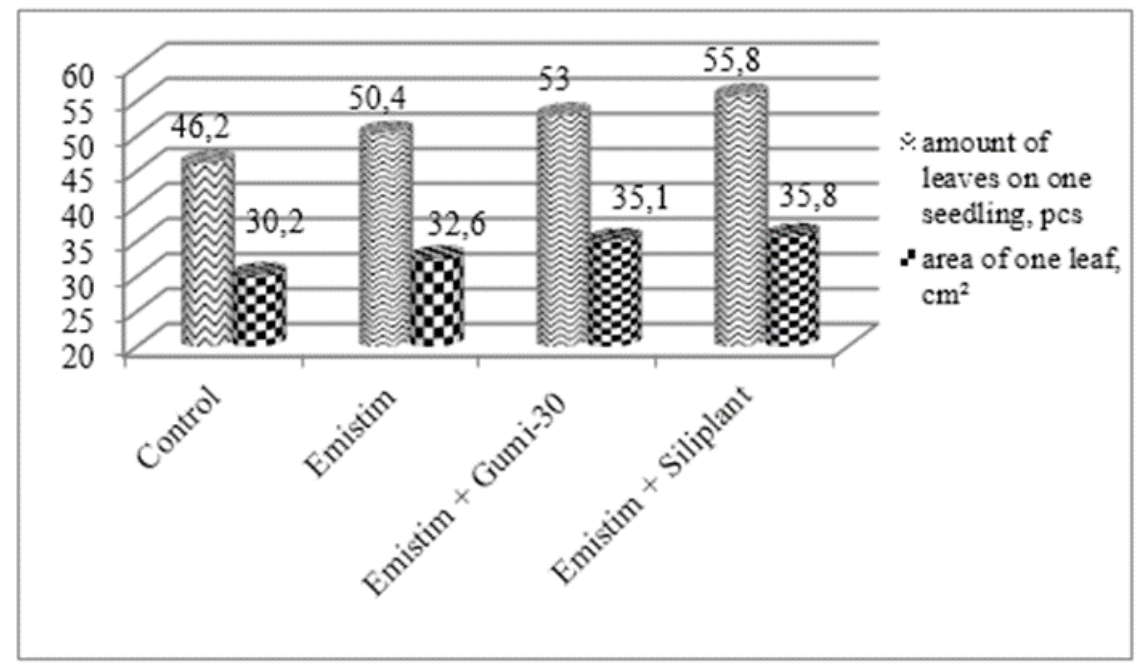

Fig. 2. The foliage of pear seedlings and the leaf area.

According to the variants of the experiment, the seedlings differed in the development of the root system. It is known, that the pear tree has a tap root system. The average number of lateral roots varied from 4.9 to 8.5 pcs., The total length of the roots - from 75.2 to $125.8 \mathrm{~cm}$ (Table 1). The increase in the relation to the control was $22.3-50.6 \mathrm{~cm}$. The difference between the 3 rd and the 4 th treatments in the studied parameters was not significant. 
Table 1. Quality indicators of the root system of pear seedlings.

\begin{tabular}{|l|c|c|c|c|}
\hline \multicolumn{1}{|c|}{ Treatment } & $\begin{array}{c}\text { the average number } \\
\text { of lateral roots, pcs. }\end{array}$ & $\begin{array}{c}\text { total root } \\
\text { length, } \mathrm{cm}\end{array}$ & $\begin{array}{c} \pm \text { to control, } \\
\mathrm{cm}\end{array}$ & $\begin{array}{c}\text { lateral root } \\
\text { diameter, } \mathrm{mm}\end{array}$ \\
\hline Control & 4,9 & 75,2 & - & 1,9 \\
\hline Emistim & 6,5 & 97,5 & 22,3 & 2,1 \\
\hline Emistim + Gumi 30 & 8,1 & 121,2 & 46,0 & 2,2 \\
\hline Emistim + Siliplant & 8,5 & 125,8 & 50,6 & 2,2 \\
\hline LSD $_{05}$ & 1,51 & 16,22 & - & $\mathrm{F}_{\phi}<\mathrm{F}_{\mathrm{T}}$ \\
\hline
\end{tabular}

The production of the standard seedlings showed the effectiveness of the biological product Emistim and complex fertilizers Gumi-30 and Siliplant. The maximum number of seedlings of the 1st grade was obtained in the variant with the treatment of Emistim + Siliplant, $-55.6 \%$ (Table 2). In the variant Emistim + Gumi 30, the production of the standard seedlings of the 1 st grade was $52.4 \%$, which is $11.4 \%$ more than in the control variant. In total, on these variants, the standard seedlings of the 1st and 2nd grade were obtained, respectively, 95.6 and $93.2 \%$.

Table 2. Productivity (\%) of standard pear seedlings.

\begin{tabular}{|l|c|c|c|c|c|}
\hline \multicolumn{1}{|c|}{ Treatment } & first grade & $\begin{array}{c} \pm \text { to control, } \\
\%\end{array}$ & $\begin{array}{c}\text { second } \\
\text { grade }\end{array}$ & $1+2$ grade & $\begin{array}{c} \pm \text { to control, } \\
\%\end{array}$ \\
\hline Control & 41,0 & - & 36,2 & 77,2 & - \\
\hline Emistim & 48,2 & $+7,2$ & 40,3 & 88,5 & $+11,3$ \\
\hline $\begin{array}{l}\text { Emistim + Gumi } \\
30\end{array}$ & 52,4 & $+11,4$ & 40,8 & 93,2 & $+16,0$ \\
\hline $\begin{array}{l}\text { Emistim }+ \\
\text { Siliplant }\end{array}$ & 55,6 & $+14,6$ & 40,0 & 95,6 & $+18,4$ \\
\hline LSD05 & 4,04 & - & $\mathrm{F}_{\phi}<\mathrm{F}_{\mathrm{T}}$ & 4,51 & - \\
\hline
\end{tabular}

A high result in the production of seedlings of the first and second grade was obtained in the variant with the treatment of seedlings with the biological product Emistim - 88.5\%. The increase in comparison with the control was $11.3 \%$.

\section{Conclusion}

The analysis of the growth and development indicators of pear seedlings of the Muratovskaya variety allowed us to draw the following conclusions:

- the biological product Emistim has a significant stimulating effect on the growth processes in comparison with the control option;

- the combined use of the biological product Emistim and the complex fertilizers Gumi-30 and Siliplant helps to increase the foliage of the seedlings, leaf area, the number of roots and their total length, and, ultimately, the yield of standard planting material;

- in the variants with Emistim and complex fertilizers such as Gumi-30 and Siliplant, no significant difference was found for the studied traits. 


\section{References}

1. W. F .A. E-G. Mosa, L. Sas Paszt, M. Frąc, P. Trzciński, Pol. J. Microbiol., 65(3), 243251 (2016). https://doi.org/10.5604/17331331.1215599

2. W. Fediala Abd El-Gleel Mosa, L. Sas Paszt, M. Frąc P., Trzciński, W. Treder, K. Klamkowski, Hort. Sci. (Prague), 45(4), $173-180 \quad$ (2018). http://doi.org/10.17221/101/2017-HORTSCI

3. R. Bhattacharjee, U. Dey, Afr. J. Microbiol. Res., 8(24), 2332-2342 (2014). https://doi.org/10.5897/AJMR2013.6374

4. D. Bhardwaj, MW. Ansari, RK Sahoo et al. Microb Cell Fact, 13, 66 (2014). https://doi.org/10.1186/1475-2859-13-66

5. Z. S. Grzyb, W. Piotrowski, P. Bielicki, L. Sas Paszt, J. Fruit Ornam. Plant Res., 20(2), 41-49 (2012) http://doi.org/10.2478/v10290-012-0014-8

6. Z. S. Grzyb, W. Piotrowski, L. Sas Paszt, J. Life Sci., 8, 889-898 (2014) 10.17265/19347391/2014.11.005. https://www.researchgate.net/publication/274076968 Treatments Comparison_of_Mineral_and_Bio_Fertilizers_in the Apple_and_Sour_Cherry_Organ ic Nursery

7. Z. S. Grzyb, W. Piotrowski, L. Sas Paszt, J. Life Sci., 9, 159-165 (2015) 10.17265/19347391/2015.04.003. https://www.researchgate.net/publication/281740892 Effect of Fe rtilization_in_Organic_Nursery for_Later_Growth_and_Fruiting_of_Apple_Trees in the Orchard

8. I. Ketut Widnyana, C. Javandira, Agriculture and Agricultural Science Procedia, 9, 419423 (2016) https://doi.org/10.1016/j.aaspro.2016.02.158

9. K. Paraszkiewicz, P. Bernat, P. Siewiera, M. Moryl, L. Sas Paszt, P. Trzciński, Ł Jałowiecki, G. Płaza, Sci. Hortic., 225, 802-809 (2017). https://doi.org/10.1016/j.scienta.2017.07.034

10. L. Sas Paszt, B. Sumorok, E. Malusá, S. Głuszek, E. Derkowska, J. Fruit Ornam. Plant Res, 19(1), 13-34 (2011) http://www.inhort.pl/files/journal_pdf/journal 2011 1/full $2 \% 202011$ 1_.pdf

11. L. Sas Paszt, E. Malusa, B. Sumorok, L. Canfora, E. Derkowska, S. Głuszek, Advances in Microbiology, 5(1), 40-53 (2015). http://doi.org/10.4236/aim.2015.51005

12. E. Derkowska, L. Sas Paszt, P. Trzciński, M. Przybył, K. Weszczak, Acta Sci. Pol. Hortorum Cultus, $\quad$ 14(6), $\quad 83-96 \quad$ (2015). http://www.acta.media.pl/pl/full/7/2015/000070201500014000060008300096.pdf

13. S. Rezvyakova, E. Rezvyakova, Bulletin of agricultural science., 5(68), 3-11, (2017), 10.15217/issn2587-666X.2017.5.3

https://cyberleninka.ru/article/n/otsenkavozdeystviya-stimulyatorov-rosta-na-povyshenie-zimostoykosti-i-urozhaynosti-maliny

14. S. Głuszek, E. Derkowska, L. Sas-Paszt, M. Sitarek, B. Sumorok, Hortic. Sci. (Prague), 47(2), 122-129 (2020) 10.17221/102/2018-HORTSCI. https://www.agriculturejournals .cz/publicFiles/102 2018-HORTSCI.pdf

15. E. Derkowska, L. Sas Paszt, S. Głuszek, P. Trzciński, M. Przybył, M.Frąc, Acta Sci. Pol. Holtorum Cultus, 16(3), 75-83 (2017). http://doi.org/10.24326/asphc.2017.3.8

16. S. Rezvyakova. A. Gurin. Fruit and viticulture in the South of Russia, 64(4), 78-88 (2020). http://doi.org/10.30679/2219-5335-2020-4-64-78-88 